\title{
ITALY AT 150: STILL A DIVIDED SOCIETY HAS THE ITALIAN STATE GIVEN UP ON THE MEZZOGIORNO?
}

\author{
Laura Polverari \\ European Policies Research Centre \\ School of Government and Public Policy \\ University of Strathclyde \\ laura.polverari@strath.ac.uk \\ [DRAFT - Not for quotation]
}

\section{INTRODUCTION}

As Italy celebrates $\mathbf{1 5 0}$ years of life as a unified State, it remains a divided country. Notwithstanding decades of explicit regional policies and the constitutional commitment that all Italian citizens have equal rights, access to essential services and minimum living standards irrespective of where they live, not just the North-South divide remains sizeable but its overcome may be challenged even further by recent political, institutional and economic developments.

Much of the intervention to redress the North-South divide after the Second World War took the form of large public investment programmes and subsidies to firms, under the so called "Special Intervention" for the Mezzogiorno. Successful during the first 15 years in determining high growth rates and a reduction of the per capita income gap between Mezzogiorno and Centre-North (Barca 2001), on the whole it failed to "develop an autonomous and competitive industrial base" in this area (Sykes 1998). As a result, the Special Intervention was abolished in the early 1990s and replaced, after a brief period of stalemate, with a 'new regional policy', the nuova programmazione. This entailed a shift towards an endogenous development paradigm, characterised by the emphasis on the exploitation of underutilised potentials and local actor mobilisation, programme-based strategies, and implementation through the ordinary administration of the State, at both national and regional levels.

The present contribution focuses on this last phase of Italian regional development policy, with a particular emphasis on developments occurred during the past there years. A number of reasons led to frame the paper in this way: first, whilst there is copious evidence on the successes and failures of both the Special Intervention and the nuova programmazione (as implemented during the 2000-06 programming period), the most recent developments in Italian regional policy have not yet been examined. Second, for the first time since the end of the Special Intervention, from the beginning of the 2007-13 programming period Italian regional policy for the Mezzogiorno does not coincide with cohesion policy. This lack of coincidence provides the room for a test on the sustainability of the domestic side of the policy, which is not subject to the same 'external' (European) constraints that apply to its cofunded counterpart. Lastly, the period from 2007 to date has represented a phase of substantial impasse in the implementation of the policy: the domestic side stalled, whilst 
the EU-confinanced side met considerable delays, with spend below the average levels of 2000-06: the causes of this poor financial performance are yet to be fully ascertained.

This paper will show that a primary factor in determining the nuova programmazione's disappointing performance has been the lack of political commitment, which has culminated in the substantial departure from this policy approach. It will also demonstrate that beyond the political rhetoric on the importance of the Mezzogiorno, in reality the goal of the development and catching up of this area is not a primary concern of the current Government's agenda.

\section{THE NORTH-SOUTH DIVIDE TODAY - SOME DATA}

The North-South economic and social divide in Italy is a long-standing question that has accompanied the life of the Italian State since its birth as a putative unitary country in 1861. The first policy action to address the socio-economic backwardness of this part of Country dates back to the Giolitti age, when the first special laws to this purpose were approved. ${ }^{1}$ Since then, the need for a policy response to the 'Mezzogiorno question' - la questione meridionale - has been a constant feature in the Italian political debates, albeit with policy responses that have changed markedly, both in terms of rationale and intensity, over time.

Yet, abundant evidence - from the statistics of the national statistics institute (ISTAT) to the studies by SVIMEZ, the Bank of Italy ${ }^{2}$ and the Department for Development and Economic Cohesion, to the research of independent regional economists and economic geographers ${ }^{3}$ - shows that this duality remains still today a fundamental aspect of the country's political and social landscape. Indeed, over the past decade, it has even worsened.

As a way of background for the analysis that will follow, let us consider the situation today: despite a slight convergence trend during the 2002-08 period (largely caused by the different demographic dynamics in the two parts of the country, notably, South-to-North migration and the higher number of foreign immigrants in the North), GDP per capita in the Mezzogiorno continues to be consistently lower than the national and EU averages (Ministero dello Sviluppo Economico 2009). In 2010, the Centre-North had a GDP per head of $€ 29,869$ (c. US\$ 42,640), against a mere $€ 17,466$ of the South (c. US\$24,934) and a national average of $€ 25,583$ (c. US\$36,522) (SVIMEZ 2011). In 2009, none of the eight Mezzogiorno regions had a level of GDP in line with the national average, against all but one CentreNorth regions (Umbria) (Bianchi et al 2011). Economic analyses concur that a real and sustained GDP convergence process occurred only until the mid 1970s (Franco 2010; Iona et al 2010).

\footnotetext{
${ }^{1}$ Those passed for region Basilicata in 1904, following a visit of Minister Zanardelli to the region in 1902, that for the industrialisation of Naples, also of 1904, and those for Calabria, Sicily and Sardinia, which were passed in the years 1906-07 (Carabba, p. 9).

${ }_{2}^{2}$ As those presented in the volumes edited by Cannari (2009) and Cannari and Franco (2010).

${ }^{3}$ E.g. more recently, Viesti 2009.
} 
Employment and unemployment dynamics also show the significance of the regional problem. The employment rate of working-age population differential between the two parts of the Country was in 2010 of 20 percentage points (64\% in the Centre-North versus 43. $9 \%$ in the South) whilst in the same year in Southern regions less than half of the active working age population was in employment (with particularly low peaks in Campania, where the employment rate was under 40\%) (SVIMEZ 2011, p. 15). What's more, the employment rate of young people (14-34) was of only $31.7 \%$ in the Mezzogiorno, against a rate of $56.5 \%$ in the rest of the country. In similar vein, unemployment levels in the South are considerably higher than in the remainder of the country. According to the most recent SVIMEZ calculations, the average unemployment rate in the Mezzogiorno in 2010 was $13.4 \%$ 7 points higher than in the Centre-North, but with the aggravating circumstance that "whilst in the Centre-North the loss of jobs tends to transform itself almost entirely in the search for new jobs. In the Mezzogiorno, on the contrary, this transforms itself only in a minimal part in explicit research of a new occupation, contributing [instead] to feed the area of inactivity and the irregular employment" (SVIMEZ 2011, p. 15). SVIMEZ has estimated that if one included also the workers in receipt of unemployment benefit ${ }^{4}$ in the unemployed statistics and those who are not in employment but also not actively seeking a new job, the actual figure of unemployment in the Mezzogiorno during 2010 would rise to just over $25 \%$ against a figure of around $10 \%$ in the Centre-North ('corrected' unemployment rate) (SVIMEZ 2001, p. 16), a figure which is similar to that reported by CNEL in its latest annual report on the labour market (24.5\% CNEL 2010a).

More than two thirds of citizens below the poverty threshold (relative poverty indicator) live in the Mezzogiorno (Franco 2010), where also more generally, private household consumption statitstics show that families, not least as a result of the recent recession, find it harder to make ends meet (as shown by a contraction in the expenditure for primary goods, compared to a stable situation in the remainder of the country) (SVIMEZ 2011).

The recent economic crisis has also shown that the economic structure of the Mezzogiorno is structurally weaker and more vulnerable than in the remainder of the Country. Italy on the whole has been badly hit by the recession, with a fall of 5 percent in real GDP in 2009 compared to 2008, due largely to a fall of foreign exports (European Commission 2010, p. 99). However, while past exogenous crises generated more severe effects in the industrialised, more dynamic and open Centre-North and the Mezzogiorno was shielded by the less open nature of its economy, the recent crisis has affected the South as well

\footnotetext{
4 The so called Cassa Integrazione Guadagni (Income Integration Paydesk). This is a support instrument for firms in difficulty, which funds part of the salary of workers forced out of work for a certain period of time. Such support can be Cassa Ordinaria or Cassa Straordinaria, depending on the type of firm and difficulties faced. The Ordinary Cassa is an intervention for the support of firms that are experiencing difficulties due temporary events and for which the slowdown of production is also temporary. It guarantees the workers a substitute income for a limited period of time. The Special Cassa has a similar goal, but provides support for a longer period of time and to a broader range of activities (not just industrial but also including commercial, tourism and transport firms - though with specific limits as regards the minimum number of total employees covered). It can be requested by the firms in cases of restructuring (technological change), reorganisation (organisational change) or re-conversion (change of activity) or in the event of the firm's crisis. For more detail: www. inps.it and Ministero dell'Economia e delle Finanze (2009) Documento di Programmazione EconomicoFinanziaria per gli anni 2010-2013).
} 
(SVIMEZ 2009 and 2011; Banca d'Italia 2009). ${ }^{5}$ Indeed, the recession has had a more pervasive and longer-lasting effect in this area of the country (Novacco 2010). Whilst GDP in the Centre-North has started to pick-up in 2010, the Mezzogiorno is still stagnating (SVIMEZ 2011, p. 2) and, as a result of the crisis, has fallen back to GDP levels equivalent, in absolute values, to those of 10 years ago (Padovani 2011, p. 12).

Nonetheless, the above picture should be read in conjunction with the fact that during the past ten years the entire country, not just the Mezzogiorno, has stalled, as demonstrated by the fall of per head GDP relative to the EU27 average of 15 points between 2000 and 2009 (Dipartimento per lo Sviluppo e la Coesione Economica 2010, p. 7). This fact has led to a new vision of the regional problem according to which the underdevelopment of the South cannot be conceived solely in terms of the traditional gap of per capita GDP and employment/unemployment rates, rather as pertaining to the persistence of "socially unsustainable gaps, in terms of quality of services essential to the life of citizens, unmotivated for a national state" (Barca 2010, p. 175) and contrary to the Italian Constitution, according to which all citizens, irrespectively of where they live, are entitled to a level of essential services guaranteed across the national territory (art. 117). This gap concerns the availability of basic essential services - such as nurseries, schools, adequate healthcare and physical infrastructure, e.g. in the fields of transport, waste and water which remain in the Southern regions below the national average. It is on these areas that current regional policy is placing particular emphasis.

Whatever measurement of the North-South divide is used, the key issue is that it is still substantial, and a fundamental question is why it is still so marked after decades of regional policy intervention. This question acquires particular relevance if one compares the Mezzogiorno to the way east Germany has caught up with the west of the country with regard to the availability of high quality infrastructures and human capital (Cannari and Franco 2009); the improvements in southern Spain in the provision of essential public services (now at levels equivalent to the rest of the Country) (Barca 2010); and the economic growth and catching-up realised by the lagging regions in Eastern Europe (Cannari et al 2010a).

The present paper attempts to answer this question focusing particularly on the last ten to fifteen years of regional policy intervention, the period that has marked the rise first and then the fall of the so called "nuova programmazione" (new programming).

\section{THE EVOLUTION OF THE POLICY RESPONSE - FROM THE NUOVA PROGRAMMAZIONE TO THE PIANO SUD}

As in other European countries, regional policy in Italy became a fundamental part of economic policy after the second world war, "when it found resonance in wider discourses

\footnotetext{
${ }^{5}$ One of the explanations for this is that firms in the North, strongly affected by the rapid fall in foreign demand were swift to react to the recession, cutting their demand for labour, raw materials, semi-manufactured products and investments. By so doing, they transmitted the impact of the crisis quickly to the more inward-oriented Mezzogiorno (Banca d'Italia 2009, p. 5).
} 
internationally of what has subsequently been called national spatial Keynesianism" (González 2011, p. 65; see also Lepore 2001, Maes 2008, Saraceno 1983). At this time the "Special Intervention" for the Mezzogiorno was inaugurated, with the establishment of a special fund (Law 646/1950), entrusted to a special agency (Gualini 2004, p. 82) ${ }^{6}$. The special intervention would be abolished in 1992, amidst criticism of lack of effectiveness, accountability and, in later years, allegations of clientelism in the handling of subsidies and dominance of political and party interest over economic efficiency as the guiding principle for localising investments (Ruffolo 2011; Gualini 2004; Barca 2001; Trigilia 1992; Sykes 1998). It would be replaced with an 'Ordinary Intervention' - i.e. a policy delivered through the ordinary public administration - for 'depressed' areas throughout the country. This shift would soon be followed by a new approach to regional development, which has become known as the nuova programmazione (new programming). The nuova programmazione was in many ways antithetic to the Special Intervention, not just with regard to the administration of policy, but also in its strategic rationale, based on the concept of endogenous development, to be achieved through the mobilisation of local actors, rather than top-down planning. It essentially reversed the perspective of the Special Intervention: whereas the Special Intervention targeted industrial development, assuming that this would bring social, civil and institutional development, the nuova programmazione focuses on the construction of social capital, believing that this would lead, in the longer run, to a virtuous growth (Cannari et al 2010b, quoted in Servidio and Prezioso 2011).

Launched in 1998 with the strong endorsement of the then Treasury Minister Carlo Azeglio Ciampi in a document called "One hundred ideas for development" (Ministero del Tesoro, Bilancio e Programmazione Economica 1998), the nuova prorgammazione tallied with a wider decentralisation reform process promoted at the same time by the Italian Government (the so-called Bassanini legislation) and resonated well with the emerging new paradigm for regional development which was being promoted by the OECD and the European Commission based on a shift from a compensation to endogenous development and focused on regional competitiveness, to be achieved through the full exploitation of underutilised local assets and resources (OECD 2003; Bachtler 2001; Bachtler and Raines, 2002), what would later become known as a 'place-based' approach (Barca 2009). Operationally, the new policy in Italy was delivered mainly through the 2000-06 generation of cohesion policy programmes (under which Italian regional policy overall ended up being subsumed). For the South of Italy, this consisted of a supra-regional Community Support Framework implemented by 14 Operational Programmes: 7 regional programmes (to which were assigned circa $70 \%$ of the resources) and 7 national ones (for areas where national direction or coordination was deemed necessary or involving interventions of supra-regional scale).

In this same period, an important development took place also with regard to the domestic side of regional policy: in 2003 the Fund for Underutilised Areas was created, to bring the different strands of domestic regional policy that existed under various budget lines into a

\footnotetext{
${ }^{6}$ The "Cassa" for the Mezzogiorno. It was transformed, in 1986, in Agency for the Mezzogiorno (also known as Agensud), but would be definitively suppressed soon after. A detailed review of the different stages that characterised the Special Intervention can be found in Gualini, 2004, pp. 81-100. For a synthetic commentary of the special intervention see also Barca (2001).
} 
single framework, thereby improving clarity, transparency and longer-term predictability. It was a first step towards the integration of the two streams of funding for regional development - European and domestic - into a single framework, as anticipated in the document "100 ideas", and that would be introduced, only in principle as will be seen, in the new regional development strategy for the period 2007-13, the so-called National Strategic Framework.

The 2000-06 programming experience concluded with mixed and on the whole disappointing results, with achievements below the targets established at the outset (Barca 2006). This generated the much welcomed emergence of a debate on the successes and failures of regional policy in this period, for instance: the copious analytical and reconnaissance work undertaken by SVIMEZ, including a number of recent initiatives organised to mark the 150 years from unification; a research programme by the Bank of Italy (which culminated in two seminars held in 2009); a parliamentary inquiry which took place in 2010-11. ${ }^{7}$ Whilst acknowledging that the lower-than-planned performance was due to causes that were largely beyond the reach of regional policy (such as the poorer than anticipated trends in the global economy), this debate brought forward a number of well founded criticisms to the nuova programmazione, including: the fragmentation of policy into a myriad of projects, which has been deemed detrimental to the achievement of the necessary critical mass (especially in certain areas of expenditure); the excessive localism in the policy choices made; the ineffectual central level coordination and guidance; the excessive emphasis placed on spend and spending capacity rather than on results (not least due to the considerable use of so called 'coherent projects', which absorbed almost one third of the total spend); related, an overall low quality of the projects implemented; and, the delays and difficulties met with project implementation, not least due to the preferential use of 'negotiated instruments' such as the territorial pacts, programming contracts and integrated territorial projects (Padovani 2011; Servidio e Prezioso 2011; Cannari et al 2010a; CNEL 2010a; Rainoldi 2010).

However, notwithstanding these weaknesses, what should be noted first and foremost is the fact that the new strategic and operational approach pursued by the nuova programmazione had already been de facto dismissed, or at least debunked, before much of above analytical work. A central argument of this paper is that this shift was due primarily to political rather than policy reasons, and that it had less to do with the lack of effectiveness of the policy paradigm pursued until by the nuova programmazione. The vicissitudes of the 2007-13 National Strategic Framework - a new strategic document introduced by the European regulatory framework for 2007-13 - are particularly illustrative of this, in that they mark the progressive realisation of a gradual shift, implicit and concealed at first, that became increasingly overt over time, which culminated in the recent approval of the 'Plan for the South'.

\footnotetext{
${ }^{7}$ Camera dei Deputati, V Commissione (Bilancio, tesoro e programmazione), Indagine conoscitiva sull'efficacia della spesa e delle politiche di sostegno alle aree sottoutilizzate; minutes of the meetings of the Commission are available from http:// www.camera.it/ 459?eleindag=/_dati/leg16/ lavori/ stencomm/ 05/ indag/ sostegno.
} 


\subsection{The journey of the 2007-13 National Strategic Framework}

Towards the end of the 2000-06 programming period, the Italian Department for Development and Economic Cohesion launched a process of technical work and partners' consultation (both vertical and horizontal) aimed at the drafting of the National Strategic Reference Framework 2007-13, a document requested by the new Structural Funds regulations for the 2007-13 period. ${ }^{8}$

Strategically this document placed itself in a line of continuity with the economic development paradigm pursued during the previous period - as it retained the endogenous, place-based, competitiveness-oriented approach ${ }^{9}$ - but took this further, introducing a number of innovations, notably:

- The affirmation of a new 'unitary regional policy' that would merge both strands of regional policy - EU (funded by Europe's cohesion policy) and domestic (funded by the FAS) - into a single, 7-year strategic framework. This marked "a real discontinuity with the past: for the first time since the closure of the special intervention in the Mezzogiorno and from the birth of the 'ordinary' intervention in the depressed areas, one is able to bring back to logical coherence the different trickles of public intervention in the field of development policy, in a homogenous manner throughout the national territory" (CNEL 2010a, p. 47), thus strengthening strategic planning as well as transparency and accountability.

- A restated territorial emphasis on the Mezzogiorno, intended as the aggregate of the eight Southern regions, notwithstanding the non-eligibility of almost half of these Abruzzo, Molise and Sardinia - to the so-called 'Convergence Objective' of cohesion policy (the former Objective 1). It should be borne in mind that whilst the NSF, in line with the European regulations, covers the entire country, it focuses especially on the Mezzogiorno, where it concentrates about two thirds of resources. The focus on the Mezzogiorno, rather than on the Convergence regions only, marked an attempt to detach Italian regional policy from the rigid strategic and operational constraints of the European regulations and strategies, asserting the willingness to implement a strong development policy based on domestic priorities and parameters. This goal was

8 In Italy, this document is more simply referred to as National Strategic Framework, NSF (Quadro Strategico Nazionale, QSN). Council Regulation (EC) No 1083/ 2006 of 11 J uly 2006 laying down general provisions on the European Regional Development Fund, the European Social Fund and the Cohesion Fund and repealing Regulation (EC) No 1260/ 1999, articles 27 and 28.

${ }^{9}$ From a strategic point of view, the NSF stems from the acknowledgement that the persistence of territorial disparities and the relative stagnation of the national economy necessitated a more targeted policy effort, with more focus on the key factors of weakness that impact negatively on national competitiveness: (i) the persistent failure of the State to supply collective services and to guarantee general competitive conditions; (ii) the inadequate level of competencies of both the adult population and the young; (iii) a low level of industrial innovation, linked to a weak system of research (as well as to the first two factors); and, (iv) a specific weakness and inefficiency of the capital market which is incapable of supporting entrepreneurial innovation and investment in the entrepreneurial system. From these premises, the NSF developed a strategy based on four macroobjectives, ten priorities, sixteen general objectives and a number of specific objectives descending from these. In its original configuration, the document planned to mobilise almost $€ 125$ billion of public funding, between European and domestic, over the period (Ministero dello Sviluppo Economico, Dipartimento per le Politiche di Sviluppo e Coesione 2007, pp. 75-76). 
also supported by the financial commitment to reserve $85 \%$ of the domestic fund for regional development (FAS) to this area.

- A new performance reserve system for the Mezzogiorno regions, linked, coherently with the development paradigm pursued, to the achievements realised in four key essential public services in the fields of education, child and elderly care, urban waste and water infrastructure, so-called 'obiettivi di servizio' (Brezzi and Utili 2007).

- In addition, this policy framework intended to build on the implementation of important policy decisions taken during the earlier phase, most importantly the commitment, seen as instrumental to the regional policy strategy pursued by the NSF, to ring-fence a quota of ordinary capital spending (i.e. broader public spending, not aimed at regional development) for the Mezzogiorno. Subsequent Italian Governments from $2001^{10}$ to 2007 had set the target of achieving a quota of total public capital expenditure in the Mezzogiorno (i.e. ordinary plus 'additional', i.e. for regional policy) of 45 percent. This was to be attained gradually by increasing the share of 'ordinary' capital expenditure in this macro-area to 30 percent, an intermediate measure between this area's GDP and population share (respectively of 24 and 36 percent) (Ministero dell'Economia e delle Finanze 2002, p. 122). Although these targets were never achieved in practice - on the contrary, in real terms in the period 2001-06 both ratios decreased (Viesti 2009, p. 54) - the NSF reaffirmed the validity of this goal. Less than a year later, however, both targets were de facto suppressed, having disappeared from the annual Economic and Financial Documents since 2008.

- From the profile of the governance, the new strategy anticipated a reinforced coordination role by the central Government - in a framework of further regionalisation of policy delivery (in line with the Constitutional reform of Title $V$ of the Constitution and with the reform of the system for the election of regional governors and executives) - through the mediation and supporting role of the Department for Development and Economic Cohesion. In this new framework, central administrations were left

with competencies in national strategic matters (e.g., research, security, and education), as well as the task of coordination, monitoring, and evaluation. Whilst the regional level has [...] the knowledge to select good projects, the central level has to guarantee general quality standards and consistency with the main general objectives of territorial policy. This in turn means that project selection is carried out at regional level while the central level is responsible of setting guidelines and general rules, regulating the allocation of resources, pinpointing the main targets, carrying on diagnostic monitoring and providing technical assistance (Brezzi and Utili 2007, p. 4).

All of these features were substantially weakened in the few years that followed the approval of the NSF, in a number of ways.

10 Since the Economic and Financial Programming Document for the period 2002-06. Ministero dell'Economia e delle finanze (2001) Documento di programmazione economico-finanziaria 2002-2006 (approvato dal Consiglio dei Ministri del 16 Iuglio 2001), p. 4. 
1. The unitary regional policy - The foundations of the 'unitary' regional policy were a joint, multi-annual financial plan for the policy and the implementation of a series of spending programmes - some cofinanced by European cohesion policy and some with only domestic resources ${ }^{11}$ - which together would realise the ambitious goals outlined in the NSF.

In this framework, each regional authority would not just devise and implement the Operational Programmes cofunded by the European Structural Funds, ${ }^{12}$ as had been the case hitherto, but also an operational programme outlining the use to be made over the period of FAS resources (known as PAR - Piano Attuativo Regionale). These latter programmes would also fund types of investments not eligible under cohesion policy and their role was particularly relevant for the three Mezzogiorno regions not covered by the Convergence status. These regions, in turn, would also benefit from FAS-funded national and inter-regional programmes - known Piani Attuativi Nazionali $(\mathrm{PAN})^{13}$ and Programmi Attuativi Interregionali - operating in the same policy areas for which, in the five Convergence regions, there are cohesion policy funded national and interregional operational programmes. ${ }^{14}$ An overview of this composite programming framework is presented in the diagram below.

It was through this compound (and complex!) implementation and financial framework that the goals of the NSF and the targets of the performance reserve on essential services would be achieved. However, the real basis for this ambitious framework - which required considerable planning and coordination efforts between and within different levels of government - was of course the fruition of the planned resources: not such an obvious fact, given the novelty represented by the tying-up of domestic resources for a seven-year timescale (domestic economic planning is articulated on one and three year timescales) and the wider public finance situation, characterised by a public debt amongst the highest in the developed world - $119 \%$ of GDP in 2010 (Ministero dell'Economia e delle Finanze 2011, p. 97) - and the necessity

\footnotetext{
11 The implementation of the NSF rested on a complex system of Operational Programmes - at regional, national and interregional level. Those cofunded by the European Structural Funds programmes were: (i) 42 Structural Funds Regional OPs (21 ERDF and 21 ESF), of which 32 fell under the Regional Competitiveness and Employment Objective (Centre-North regions plus Abruzzo and Molise) and 10 under the Convergence Objective (for the regions Calabria, Sicily, Apuglia, Campania and Sardinia); (ii) 8 Structural Funds National OPs, of which 7 are for the Convergence Objective (5 ERDF NOPs and 2 ESF OPs) and 1 for the Regional Competitiveness and Employment Objective (an ESF OP which is a novelty, as previously there was no national OP for the Centre-North regions); (iii) 2 Interregional OPs (IROPs) funded by the ERDF for the Convergence regions (IROP Renewable energies and energy saving, and IROP Natural and cultural attractions and tourism). In addition, those funded solely with domestic resources were supposed to be: (i) one FAS funded Regional Implementation Programme in each region; (ii) four FAS funed NOPs; (iii) and, two FAS-funded IROPs for the Mezzogiorno area.

12 The 2007-13 Structural Funds regulations affirmed a principle, which had already been experimented in Italy during the 2000-06 period in the Centre-North regions, of mono-fund programming. As a result, each regional authority had to approve and implement separately one OP cofinanced by the European Regional Development Fund (ERDF) and one OP cofinanced by the European Social Fund (ESF). Until 2006 the Objective 1/ Convergence regions had instead multi-fund programmes (which included also the Rural Development and Fishery Funds, moved since 2007 under the Common Agricultural Policy).

${ }^{13}$ Where national stands for multi-regional.

${ }^{14}$ Notably the PAN for Education, Research and Competitiveness, Network and Mobility, Governance and the Interregional Implementation programmes for Energy and Cultural attractors.
} 
to meet the stringent conditions imposed by the strengthened Stability and Growth Pact.

\section{Figure 1: The programmes contained within the initial framework of the 2007-13 National Strategic Framework}

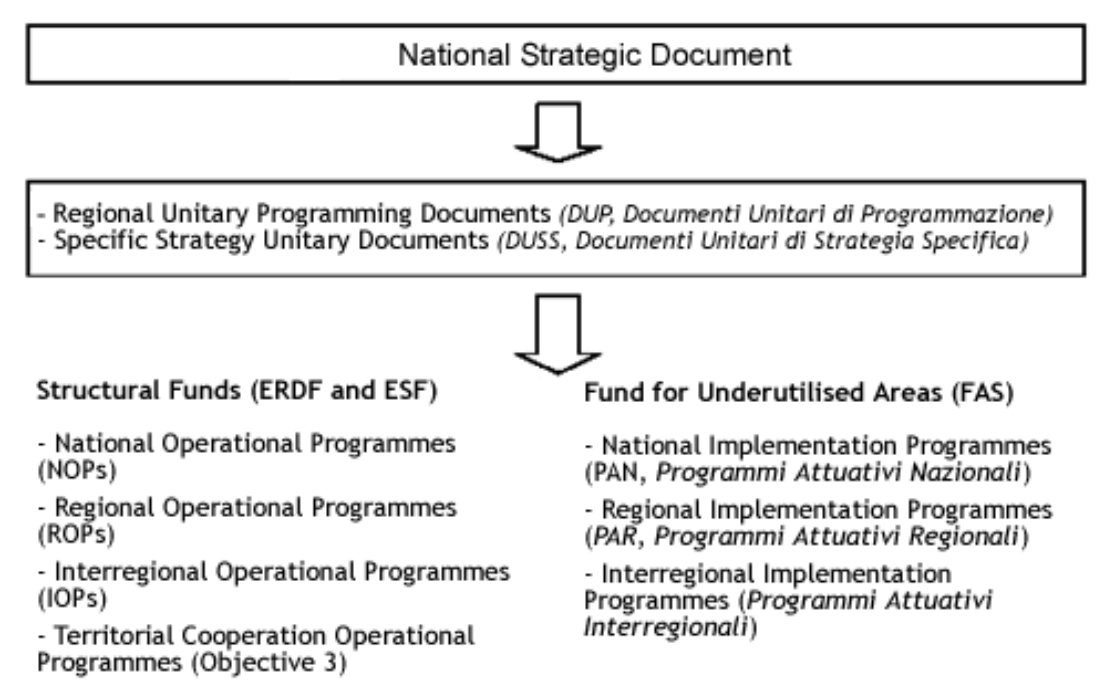

Source: Adapted from CNEL (2010a) p. 53.

And in fact, it was this fundamental condition that fell through in 2008 and 2009, when with CIPE deliberations the Government made substantial cuts and redeployments to the planned FAS resources, thus undermining the whole strategy outlined in the NSF.

Specifically, the original FAS allocation of $€ 63,273$ million $^{15}$ (for the entire period) was reduced by circa $€ 10,786$ million (-17 percent) between 2008 and 2009. ${ }^{16}$ In addition, reallocations were made from the NSF to three strategic funds, to concentrate resources on objectives deemed a priority for the re-launch of the Italian economy, but not necessarily aligned with the goals of the NSF: the development of strategic infrastructures (in particular transport networks and support for productive activities) and employment. ${ }^{17}$ Further, with the 2010 Finance Law, the Government

\footnotetext{
${ }^{15}$ CIPE deliberation no. 166/2007. The NSF had foreseen a higher allocation of $€ 64.4$ billion, but this was reduced to $€ 63,273$ million by CIPE Deliberation 166/ 2007.

${ }^{16}$ The cuts were made via a number of CIPE Deliberations: CIPE Deliberation no. 112 of 18 December 2008 and CIPE Deliberations no. 1, 2, 3 and 4 of 6 March 2009. Deliberation no. 112/2008 also cut $€ 2.44$ million from the FAS resources assigned to 2000-06 programmes (resources previously assigned by CIPE to national and regional administrations but not committed by the end of May 2008, and resources assigned to coherent projects but which had not been the subject of legally binding commitments by the same date).

17 These were: (i) a newly established Social Fund for employment and training, the resources of which were destined to finance the CIG and training; (ii) an Infrastructure Fund for actions aimed at boosting national infrastructure networks (including IT and energy networks, the implementation of safety maintenance work in schools, environmental regeneration activities, prison building, museum and archaeological infrastructure, technological innovation and strategic infrastructures for mobility, such as railway investments); (iii) a nation-wide Strategic Fund located within the Presidency of Ministers to support the real economy, competitiveness and development (also known as the Presidency Fund), without clear indication of specific destinations. These three funds operate outside the original strategy of the NSF, but in principle maintain the commitment of 85 percent earmarking
} 
also allowed regional authorities to use the 2007-13 FAS resources to partially offset their National Health Service debt, an opportunity that was seized by at least some amongst the Mezzogiorno regions (e.g. Sicily), thus undermining further the strategy of the National Strategic Framework.

As a result of the above cuts and redeployments, three out of four national FAS programmes foreseen by the NSF were abolished (those for Education, Research and Competitiveness, and Network and Mobility), whilst the regional and interregional programmes were maintained but with financial cuts in the region of 6-5 percent of the originally planned resources. The removal of these resources and the abolition of the national FAS Programmes will have a particular impact on the non-Convergence Mezzogiorno regions (Abruzzo, Molise and Sardinia). ${ }^{18}$ Clearly, the new framework resulting from the cuts and redeployments eradicates the whole unitary strategy for the Mezzogiorno outlined in the NSF. What's more, none of the regional FAS Implementation Programmes had yet been launched by the end of 2010, given the non-fulfilment by the central Government of the transfer of the related FAS resources to the regional authorities. ${ }^{19}$

2. The ring-fencing of ordinary resources - As already noted, from 2008, the Government renounced to continue pursuing both targets of $45 \%$ of total capital expenditure and $30 \%$ of ordinary capital expenditure, as these targets disappeared from the annual Economic and Financial Documents. In reality, such targets had

for the Mezzogiorno. However, as is evident, not all of these measures have a specific regional development or growth orientation.

At the same time, with Law Decree (no. 185/2008) the whole NSF was revised in an anti-crisis capacity, a task that included the appraisal of the resources left unutilised from FAS allocations for the 2000-06 period, to be released and reallocated.

It is interesting to note that a survey carried out by CNEL's Consulta per il Mezzogiorno of socioeconomic organisations at the regional level (e.g. trade unions, entrepreneurial organisations and similar) found that $96.4 \%$ of respondents assessed the unitary programming of Structural Funds and FAS resources as positive (condivisibile). Respondents viewed the cuts and redeployments of FAS of 2008 and early 2009 negatively. From the report: "The government and the Parliament, also through an agreement Government-Regions ... have considerably altered in the past months both the framework of the policy and the overall availability of resources. These modifications are judged as not agreeable by the $64 \%$ of the interviewed and agreeable only by $29 \%$ whereas the remaining $7 \%$ preferred not to comment. This is thus a rather negative assessment: in particular, almost the totality of responses criticises the destination to other aims of part of the resources of the national quota of the Fund for Underutilised areas, involved in cuts and redeployments often of little coherence with the mission of the Fund. Similarly, the concentration of resources in the three central funds is assessed negatively ..., both because this engenders the risk of a destination of the resources not to the Mezzogiorno but generically to other territories (as it is not anymore possible to guarantee the respect of the 85-15 percent repartition) and because eliminating the operational programmes the degree of political discretion in the use of resources increases, frustrating, in practice, that which the parts themselves had assessed as the main positive novelty of the new programming cycle, that is the possibility to jointly plan the resources of the Structural Funds and of the FAS" (CNEL 2010a, p.107, own translation from Italian).

${ }_{18}$ Given that the Convergence regions and Basilicata (transitional support) benefit from similar interventions under the Convergence NOPs.

${ }^{19}$ The procedures for the approval of these programmes involved the appraisal and approval by the national coordinating administration for regional policy (the Department for Development and Economic Cohesion of the Ministry of Economic Development) and subsequent confirmation by the CIPE (the Inter-Ministerial Committee for Economic Programming), followed by adoption by the Ministry of the act through which the State assumes the obligation for the annual quotas of FAS resources, as indicated in the financial plans of the Regional Implementation Programmes (PAR). 
never been achieved even prior to this act (Viesti 2009). This has resulted in the Mezzogiorno regions receiving, net of regional policy transfers, less than their 'fair share' of capital spending and in regional policy resources being used in the Southern regions to fund investments that in the remainder of the country are funded by ordinary (i.e. non regional policy) resources (Viesti 2009, p. 55; Camera dei Deputati 2010). It also caused a loss of additionality with regard to cohesion policy, as observed by the Italian Government itself in its 2009 Strategic Report on cohesion policy (Ministero dello Sviluppo Economico 2009, p. 4; Viesti 2009, p. 55; Camera dei Deputati 2010). ${ }^{20}$

3. The role of the Department for Development and Economic Cohesion - after a period of intense activism and strong leadership, coinciding with the first years of the nuova programmazione, the Department for Development and Economic Cohesion policy has been losing ground and lost the 'propulsive' force that it had exerted in these years. First, in 2006, the Department was moved from the Ministry of Economy and Finances to the Ministry of Productive Activities (now Ministry for Economic Development) which marked its decoupling from CIPE, the Interministerial Committee for Economic Programming charged with the allocation of regional policy resources. Second, in 2009, the Directorate for Studies, which had been responsible for the coordination of the preparation of the annual report on the implementation of regional policy for the Mezzogiorno, ${ }^{21}$ was suppressed and this resulted, for instance, in a delay in the production of this report both in 2010 and $2011 .{ }^{22}$ Third, the Department, in its role of interface on regional policy between the national Government and the regional authorities, has had to pay the price of the uncertainties and indeterminateness that have characterised the policy in the last few years (most notably on the availability of FAS resources and the new direction that regional policy would take under the Berlusconi Government that came to power after the approval of the NSF): this undermined its credibility in bringing forward a plan (the NSF) whose future was so evidently uncertain. The protracted internal reorganisation process within the Ministry and the political vicissitudes that led to the resignation of Minister Scajola in May 2010, including the five months of stalemate before the appointment of a new Minister, ${ }^{23}$ contributed to the Department's reduced incisiveness. Lastly, in J une 2010, the 2011-13 financial initiative reallocated

\footnotetext{
${ }^{20}$ An issue recently addressed also by the Governor of the Bank of Italy, who has emphasised that "regional policies can integrate the available resources, allowing an increased territorial concentration, contrasting negative externalities and strengthening the positive ones. But they cannot substitute the good functioning of ordinary institutions. [...] It is necessary to direct the commitment especially towards the general policies, which have objectives referred to the whole Country, and concentrate on the environmental conditions that render their application more difficult and less effective in some areas', Draghi 2009, p. 6 (own translation from Italian).

21 This report is submitted annually by the Ministry competent for regional development to the Parliament to illustrate the territorial trends in the Mezzogiorno and Centre-North and the implementation of regional policy.

22 The 2009 report was presented on 15 J uly 2010, the 2010 report is still pending. In the period 20042006 the annual reports were available at the end of J anuary (the 2005, 2004, 2003 Annual Reports), subsequently they would be made available in March/April of the following year.

${ }_{23}$ Minister Scaj ola on 4 May 2010, and the resignation was accepted on 5 May 2010; the new Minister, Paolo Romani, was appointed on 4 October of the same year. During this interim, the post was covered by President Berlusconi.
} 
the responsibility for the coordination of regional policy Ministry of Economic Development to the Ministry of Regional Affairs (a Ministry without portfolio, operating within the Presidency of the Council of Ministers, renamed as Minister for Relations with the Regions and Territorial Cohesion). This move, however, does not seem to have contributed, thus far, to reinforce the Department's role. Indeed, as the Department continues to formally sit within the Ministry for Economic Development, but is intended at the same time to support the activity of the Ministry for Regional Affairs, the new organisation seems to harbour the potential for further ambiguities on its actual role and weight.

What is still surviving from the original framework outlined by the NSF are the performance reserve system related to the obiettivi di servizio (of c. $€ 3$ billion initially, but cut by $20 \%$ with CIPE Deliberation of J anuary 2011) and the $85 \%$ ring-fencing of the FAS fund (in programmatic terms at least - the actual compliance to this threshold would have to be verified). Both measures, however, have been undermined by the recent changes discussed above: the achievement of the targets of the performance reserve on essential services for the 3 non-Convergence Mezzogiorno regions is called into question by the unavailability of FAS resources and by the suppression of the national FAS programmes (e.g. in the field of education); whilst the $85 \%$ earmarking, albeit restated as a principle, has been weakened by its reduced value in absolute terms, derived from the reduction of the total volume of FAS allocations and by the lack of cogent mechanisms to ensure the respect of this norm (which in fact, as far as the redeployments above discussed are concerned has been questioned).

\subsection{The approval of the Plan for the South}

The last instalment in the reframing of regional policy which started in 2008 has been the recent approval of the Plan for the South. After repeated announcements and postponements the main lines of the Plan were made public in November 2010. On 3 August 2011, the CIPE approved the allocation of a first tranche of resources - circa $f 7.4$ billion to 134 projects, between major national transport infrastructures (rail and roads, six large projects) and interregional, regional and local infrastructures (128 projects, not just on rail and roads, but water management, broadband and industrial infrastructures).

The Plan, a slim document of 36 pages, consists of three "strategic priorities for the development of the South"- (i) infrastructures, environment and public goods; (ii) competences and education; and, (iii) innovation, research and competitiveness - and five "strategic priorities for the improvement of the socio-economic environment and of the conditions in which citizens and firms operate": (i) safety and legality; (ii) certainty of the state of law; (iii) a more efficient and transparent public administration; (iv) the Mezzogiorno Bank; and, (v) targeted and fast support to firms, employment and agriculture.

Compared to the NSF, it includes two new priorities - on safety and legality, and on the certainty of the state of law - and discards the NSF's priorities on energy and urban systems (except for the part on urban transports) (see Table 1 below). It thus marks a departure from the approach of the NSF (and thus of the nuova programmazione). 
Table 1: Comparison between the priorities of the NSD 2007-13 and the priorities of the Plan for the South

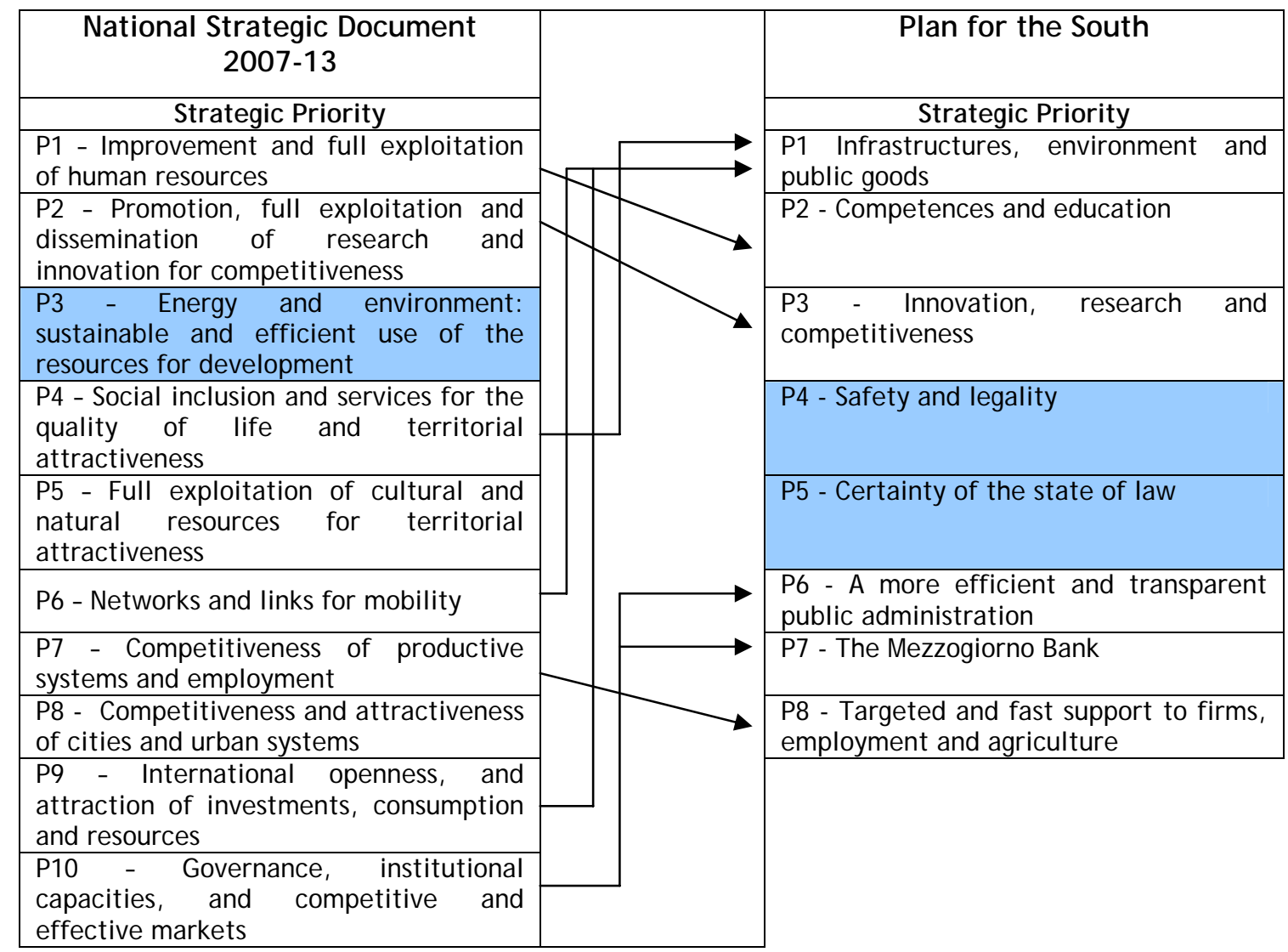

Sources: NSD 2007-13 and Plan for the South.

According to the Government, this change of direction was due to a markedly different "socioeconomic context compared to that in which the programming for the funds for the period 2007-13 had been constructed. The change of strategic priorities that derives from this is reflected for the South in the National Plan for the South". ${ }^{24}$

Although the Plan clearly aims to address some of the shortcomings of the nuova programmazione, for instance by increasing concentration and results-orientation, a key critical element of the Plan relates to the fact that it does not entail the allocation of new resources ${ }^{25}$ (indeed, in J anuary 2011, the FAS resources planned in the NSF were reduced further, with cuts reaching a cumulated level of $-25 \% .{ }^{26}$ In other words, the plan relies on

${ }^{24}$ CIPE Deliberation of 11 J anuary 2011, OJ no. 80 of 7 April 2011, point 7.

${ }^{25}$ As also remarked by the European Commissioner for Regional Policy. Letter from J ohannes Hahn, Member of the European Commission to On. Franco Frattini, Minister of Foreign Affairs, On. Raffaele Fitto, Minister for the Relations with the Regions and for Territorial Cohesion, On. Giulio Tremonti, Minister for Economy and Finances, Bruxelles, 13 May 2011, CAB/ D (2011)Ares 529187.

${ }^{26}$ CIPE Deliberation of 11 J anuary 2011, OJ no. 80 of 7 April 2011, points 9 and 10 . The figure of $-25 \%$ is based on own calculations from data contained in: in CIPE Deliberation 166/2007 (for original NSF allocations); Ministero dello Sviluppo Economico, Dipartimento per lo Sviluppo e la Coesione Economica (2010) Rapporto Annuale 2009 sugli interventi delle aree sottoutilizzate del Dipartimento per lo Sviluppo e la Coesione Economica, Rome, July 2010 (for allocations until 2011: data from pp. 231, 237 and 239); and CIPE Deliberation no. 80/2011 (for the latest cuts). It does not include the redeployments. 
the "re-programming of the funds for the South of national and community source" (Ministero per gli Affari Regionali, 2010, p. 35). This is potentially harmful because altering the content of the programmes cofinanced by European cohesion policy requires the renegotiation of these with the European Commission which is time-consuming: a problem when Italy's expenditure rate is already amongst the lowest in Europe and the programmes are already exposed to the risk of decommitment (Trigilia 2011). ${ }^{27}$

Moreover, whilst introducing measures to ensure financial rigour and speed-up expenditure (thorough new target-oriented 'institutional contracts' linked to binding 'chronoprogrammes' $)^{28}$, the Plan seems to lack the multi-annual, longer-term strategic breath that the unitary regional policy aimed to achieve. The provision that it will be updated annually on the basis of its implementation progress, moreover, poses the risk of exposing the strategy in future to fluctuating political preferences and suggests that the Plan's implementation in future years may become undermined by the same economic conditions that also determined the cuts of FAS resources from the current NSF. Despite the provision for 'concertation' with the regional authorities on the interventions implemented, the approach appears more centralist than the previous framework, which is at odd with the supposed federalist move currently pursued by the Government (as also observed by the Association of Italian Municipalities, ANCI 2010).

\footnotetext{
${ }^{27}$ According to EPRC calculations based on Commission data at May 2010, Italy is the third slowest spender, followed only by Bulgaria and Romania (Michie 2011, p. 3). Halfway through the programme period, the level of expenditure of Italian programmes is lower than it was at the same time during the 2000-06 period. According to latest data by IGRUE (the Italian Accounting Department within the Ministry of Economy and Finances), relating to the financial implementation at 31 August 2010 (data published in October 2010), the Convergence programmes have a level of commitments and expenditure of only $17.05 \%$ and $7.4 \%$ a significantly lower rate compared to the same period in 2000 06 (Polverari and Vitale 2010). Commissioner Hahn, in the above cited letter, raised concerns too, highlighting in particular the difficulties faced by the ERDF OPs of Campania, Sicily, Sardinia, Abruzzo, Lazio and Cultural Attractors.

It should be noted that the Government has taken action to speed up the expenditure of cofinanced programmes and to avoid automatic decommitments in the framework of cohesion policy. First, a short term measure which was taken to accelerate the expenditure in 2011 was to re-programme the regional OPs, so that they can fund investments in the fields of education and $R \& \mid$ which have already been positively appraised under the NOPs dedicated to these themes, but not funded due to lack of resources (the ROPs also include these two priority themes). Second, with longer-term perspective, and also to give a strong signal about the Government's commitment to ensure that resources are not lost through decommitment, the Government has set up a strict plan of commitment and expenditure targets for each co-funded OP, with verifications on 31 May 2011 and 31 December 2012 for the levels of commitment and on 31 October 2011 for the levels of expenditure. Those programmes which will not have achieved their commitment and expenditure targets will see their financial allocations reduced and reallocated to other programmes (allocations 2013). This is a domestic sanctioning mechanism, that would precede (and, hopefully, prevent) possible $\mathrm{N}+2$ sanctions. The first verification was on 31 May and the results were notified on 15 J une. The measure was successful in determining a strong acceleration of commitments, with only two programmes not achieving targets: the Interregional OP Cultural Attractors and the ROP Sardinia. The former will see its resources cut and reallocated to other programmes (c. $€ 15$ million, thus a symbolic/ pedagogic sanction), the second will carry out an internal reallocation (due to its Phasing In status and the fact that it is the only Phasing In programme in Italy, i.e. resources from this programme could not be reallocated to other programmes).

${ }^{28}$ It is interesting here to note the repechage of a term introduced in the very first years of the nuova programmazione. See CIPE Deliberation of $11 \mathrm{~J}$ anuary 2011, OJ no. 80 of 7 April 2011.
} 


\section{CONCLUSIONS}

What strikes from the above review is that the current Berlusconi-led Government marked a halt of the regional policy effort to develop the Mezzogiorno. This sits oddly with the electoral loyalty manifested by these territories to the Centre-Right (six out of eight Mezzogiorno regions are currently governed by Centre-Right coalitions: Abruzzo, Molise, Campania, Calabria, Sicily and Sardinia).

The current Government's initial ambiguous, perhaps concealed behaviour with regard to the National Strategic Framework 2007-13 (including the virement of resources towards other policy priorities) and the subsequently more overt shift from it, embodied by the Plan for the South, have caused a substantial halt in regional policy for more than half of the current programming period. This will have harmful consequences for the socio-economic development of the region, but may also be detrimental to the future availability of already budgeted EU resources, placed at risk of decommitment by the low spending performance achieved thus far (generating, prospectively, an even higher impact on the socio-economic condition of the region). The abandonment of the commitment (never achieved) to rebalance the proportion of capital spending flowing to the two parts of the Country also contributes to condemn the Mezzogiorno to its lagging status compared to the rest of the Country, as it undermines regional policy. The approval and launch of the Plan of the South with no additional (in fact with reduced) resources, three years after the Government took power in May 2008, cannot be viewed as a serious commitment but rather as a political manoeuvre to promote the image of a Government, and of some of its members, that is sensitive to the Mezzogiorno question, whilst at the same time redirecting the few available domestic public resources towards projects close to the heart of the Government (an important consideration at a time of strong financial tightening). ${ }^{29}$

There is today abundant evidence on the successes and failures of the nuova programmazione. This evidence shows that - in addition to the conceptual and operational weaknesses noted in section 3 - the failure of the new regional policy was largely due to the lack of synergy and coherence with domestic ordinary public spending and its territorial distribution (Padovani 2001; Cannari et al 2010a; Barca 2010). As observed by Cannari et al, "additional capital expenditure in the South is in the region of 5 percent of the total public spend in the area. It is self-evident that what matters is the total expenditure and its quality ... it is difficult to imagine that the regional policies with 5 percent of the expenditure could significantly affect the development of the lagging areas" (Cannari et al 2010a, p. 170). It is legitimate to assume that, had the present Government been serious about overcoming the Southern question it would have insisted on this lever, rather than the reverse, that is reducing the already planned resources for domestic regional policy (the 5 percent).

${ }^{29}$ On 13 August 2011 the government had to pass an austerity package (not yet voted by the Parliament), after its already severe financial initiative of $17 \mathrm{~J}$ uly which had already cut significantly public expenditure, including the transfers from the central state to the sub-national authorities, raising questions, amongst others, over the feasibility of the fiscal federalist reforms. 
But a similar lack of interest by the political class towards regional policy for the Mezzogiorno can be traced back to the mid 2000s (Barca 2006, 2010), as witnessed for instance by the 'stop-and-go' course of regional incentive schemes (Barca 2006; Servidio and Prezioso 2011) and, since 2007, their virtual abolition (Servidio and Prezioso 2011). The mid term evaluation of the 2000-06 Community Support Framework (CSF) had noted already in 2003 that

"the CSF pays for, in a number of programmes and areas, a substantial 'solitude' and for the self-referentiality of its ruling class ... the CSF appears 'isolated' - indeed it is more so than in 1999 - from the remainder of the PA ..., of Politics, of the social and economic parts, and most of all of Civil Society" (Vision \& Value \& The London School of Economics 2003, pp. 14-15).

The same evaluation report also noted that, at the regional and local levels, it was the engagement of the political classes that made the difference, observing that the attitude of politicians was the factor that explained the majority of the differences in the implementation performance of programmes, with the result that "a stronger, more continuous and more transparent involvement [of the political level] improves the performance" (Vision \& Value \& The London School of Economics 2003, pp. 14-15).

So, already mid-way into the past programme period much of the political commitment towards regional policy and the nuova programmazione had gone lost. This lack of interest was however tempered, in its effects, by the substantial geographical coincidence of the policy for the Mezzogiorno with cohesion policy (with the exception of Abruzzo). This coincidence allowed a team of technocrats, both at national and at regional levels, to attempt to continue - under the 'protection' of the rules of European cohesion policy - the reform process initiated with the "One hundred ideas". In the meanwhile, this had started to bear fruits, most notably with regard to the improvement of public administration capacities in the Southern regions, where even a spillover effect on the wider public administration could be detected (Vision \& Value and The London School of Economics 2003). Without continued support from the political élites, however, this action transformed into a technocratic and 'self-referential' exercise - could not be sustained and even the formidable results achieved with regard to the administration of the policy, in terms of planning, monitoring and evaluation, could not always be continued, as witnessed by the recent retrenchments reported in some regions: the simple fact that it has been necessary to reintroduce 'chrono-programmes' and financial targets for the cofinanced programmes is a patent sign of this regression.

On the whole, thus, one can share the assessment made by Carabba that the "lack of interest towards the South is contrasted, with some result, only by the cycle of negotiated programming opened by Ciampi Minister of Treasury in 1996 (with the technical guidance of Fabrizio Barca" (2011, p. 12, own translation).

But what have been the reasons for this supposed lack of political commitment towards the development of the South? According to Fabrizio Barca, 
the policy launched in 1998 ... triggers in the Mezzogiorno a violent opposition: resistance, attacks of any sort. Strong interests are at play and many local ruling classes grown on rent positions and on bad administration risk to lose their privileges. In this situation, apart than in the first year of the strategy, in Rome national politics pretends not to hear, or worse (Barca 2010, p. 176, own translation from Italian).

Looking at the most recent period, that from 2008 to date, it would seem that the NSF 'went too far'. Its allocation of copious amounts of domestic resources to the development of the Mezzogiorno proved not palatable to national politicians preoccupied with running national economic policy in a context of increased fiscal austerity and with maintaining consensus among the electorate in the North, traditionally more engaged in politics and more 'demanding' vis-à-vis the public actor. ${ }^{30}$

As noted, until 2000-06 regional policy for the Mezzogiorno had largely coincided with European cohesion policy. Maximising cohesion policy receipts, including by ensuring the availability of the necessary domestic cofinancing and a satisfactory financial implementation (so as to to avoid decommittments) was an obvious goal, given Italy's net payer status in the European budget (and the fact that cohesion policy is the budget heading that moderates this net payer position). The fact that virtually all Mezzogiorno regions until the end of 2006 were eligible to the most intense form of support under cohesion policy - the Objective 1 - accomplished a double achievement: on the one hand, it maintained into existence a financially consistent policy package for this region (comparable to that which had been in place under the Special Intervention); on the other, it ensured the certainty of domestic confinancing allocations: having been included in binding programmes, approved by Bruxelles, such commitments had to be maintained. It could not affect the domestic side of regional policy, of course, but this was rather marginal.

This situation changed considerably in 2007, when three regions exited the Objective 1 (now renamed Convergence Objective). The attempt made to compensate this with a much strengthened domestic side of the policy failed partly exactly because, for this area of spend, the external constraint represented by Brussels was not there. Further factors were the effects of the recession and the poor spending performance by the FAS fund in 2000-06. The stagnation that the country experimented in the past decade, aggravated by the recent recession, led to the emergence of a 'northern question' (González 2011), according to which the Centre-North too needs to be supported to regain competitiveness (besides, it is argued, if the country's wealthier vanguards are struggling, how can the backward Mezzogiorno be expected to do well?). Whilst the delays in the use of FAS allocation in the

\footnotetext{
${ }^{30}$ In this regard, it is interesting to quote a study by Giordano et al (2009) which examined the levels of efficiency for four essential services (education, healthcare, justice and nurseries) in all Italian regions and related these to citizens' engagement in public life and their more or less active monitoring of the activity of policy-makers. They found that the efficiency was higher where the participation in political life was also higher and concluded that "at whichever level of government, a well functioning administration requires an active participation by the citizens, their willingness to invest time and resources to control and, if necessary, punish inefficient politicians at the time of elections", p. 275.
} 
Mezzogiorno prompted the Government to call into question the absorption capacity of the Southern regions, providing a justification for the cuts to the FAS allocations for 2007-13.

In sum, even though there have been a number of shortcoming in the nuova programmazione, what has failed rather than the policy seems to have been the commitment of the political class to really 'invest' in it, also by redressing the balance of capital expenditure flowing to the two macro-aggregates and by achieving a more effective synergy between regional policy and the sectoral policies and broader public spending. It would thus appear that if after 150 years from its unification and 20 years from the end of the Special Intervention Italy remains a divided Country, this has not just been due to the pursuit of a 'wrong' policy response, but also to the lack of genuine political commitment. Political engagement has failed at the national level - as the events above discussed have shown - but also, as demonstrated by the extremely poor spending performance of cofinanced programmes, at regional level (inexplicably given the current financial climate).

But how can this be explained? In 1911, 50 years after unification, Leopoldo Franchetti, a well-known politician and meridionalist of the time, wrote:

The fact is that, from 1861 onwards, all governments of whichever party have seen in the Mezzogiorno of Italy not a Country to govern, but a group of deputies to reconcile [...] the Italian State has believed, erroneously, that it was necessary to renounce to its high office to obtain votes in Parliament [...], until the past decade it has renounced to undertake the part that it should play in the solution of the fundamental problem for the redemption of the Mezzogiorno: the problem of its economic regeneration (Franchetti 1911, p. 23, own translation from Italian).

Reading this statement with the above by Fabrizio Barca leads us to question how much has changed in over 100 years in the social fabric of this region and of Italy as a whole. Perhaps just like 100 years ago the goal of the development of the Mezzogiorno is secondary to the maintenance of the political status quo, both nationally and in the regions, which citizens in the South have so far been not interested or capable of challenging.

A final question has to be raised on the future institutional set-up of the country and of the Southern question in the new federalist organisation of the State that is now taking shape. Whereas the current Government has been tepid towards to the regional policy cause, it has been active - under the constant menace of the Northern League - in pursuing the completion of the federalist framework anticipated by the constitutional reforms of 2001. After approving law no. 42/2009 on fiscal federalism ${ }^{31}$, the Government issued a number of implementation decrees, including a recent one on art. 16 of the law, on the "additional resources and special interventions for the removal of economic and social disequilibria" (in compliance with art. 119 of the Constitution). ${ }^{32}$ It would be premature to attempt to make an assessment of the impact of these reforms on the Southern regions' socio-economic

\footnotetext{
${ }^{31}$ Law 5 May 2009, no. 42, "Delegation to the Government on the subject of fiscal federalism, for the implementation of article 119 of the Constitution", OJ no. 103 of 6 May 2009.

32 Which, inter alia, renames the FAS, Fund for Underutilised Areas, as "Fund for Development and Cohesion".
} 
condition, and it would certainly require an in depth empirical consideration that is well beyond the ambition of this contribution. However, what can be noted is that although the revised Constitution entrusts the protection of citizenship rights to the exclusive competence of the State (art. 117), the effective realisation of this provision will have to rely on the realisation of an effective vertical and horizontal solidarity (Carabba 2011), which in turn would require the emergence of a national consensus on this idea. In the light of the above discussed developments, at present this appears unlikely. 


\section{BIBLIOGRAPHY}

ANCl, Comitato Direttivo (2010) Piano nazionale per il Sud, Ordine del Giorno, Rome 2 December 2010.

Banca d'Italia (2009) Economie regionali. L'economia delle regioni italiane nell'anno 2008, Rome, 2009/61.

F. Barca (2010) intervention at the seminar "The Mezzogiorno and the political economy of Italy", Rome 26 November 2009, in L. Cannari e D. Franco (eds.) II Mezzogiorno e la politica economica dell'Italia, Banca d'Italia, Seminari e convegni, n. 4, giugno 2010, pp. 173-179.

F. Barca (2009) An Agenda for a Reformed Cohesion Policy. A place-based approach to meeting European Union challenges and expectations, Independent Report prepared the request of Danuta Hübner, Commissioner for Regional Policy, April 2009.

F. Barca (2006) Italia Frenata. Paradossi della politica per lo sviluppo (Donzelli, Rome, 2006).

F. Barca (2001) New trends and policy shifts in the Italian Mezzogiorno, paper published on Daedalus, Spring 2001 "Italy: Resilient and Vulnerable, Volume I: The European Challenge", Issued as Volume 130, Number 2, of the Proceedings of the American Academy of Arts and Sciences (online version consulted: http:/ / users. ox. ac. uk/ - hine/ seminarpapers/ Barca\%20seminar\%20paper. doc ).

L. Bianchi, D. Miotti, R. Padovani, G. Pellegrini and G. Provenzano (2011) Relazione SVIMEZ to the Seminar "Nord e Sud a 150 anni dall'Unità d'Italia", Camera dei Deputati, 30 May 2011.

M. Brezzi and F. Utili (2007) Targeting Financial Objectives of Public Service Provision to Expand Capabilities: A Policy Application in the South of Italy, paper presented at the Human Development and Capabilities Association Conference, September 2007.

Camera dei Deputati (2010) Indagine conoscitiva sull'efficacia della spesa e delle politiche di sostegno alle aree sottoutilizzate. Commissione V, Bilancio, tesoro e programmazione. Indagine conoscitiva, 27 J anuary 2010.

L. Cannari (ed.) (2009) Mezzogiorno e politiche regionali. Banca d'Italia, Seminari e Convegni, 2, November 2009.

L. Cannari e D. Franco (eds.) II Mezzogiorno e la politica economica dell'Italia, Banca d'Italia, Seminari e convegni, 4, J une, 2010.

L. Cannari e D. Franco "Presentazione delle ricerche", D. Franco (ed.) (2009) Mezzogiorno e politiche regionali, Banca d'Italia Seminari e Convegni, no. 2, 2009, November 2009, pp. 7-12.

L. Cannari, M. Magnani and G. Pellegrini (2010a) "Quali politiche per il Mezzogiorno?", in L. Cannari e D. Franco (eds.) II Mezzogiorno e la politica economica dell'Italia, Banca d'Italia, Seminari e convegni, 4, J une, 2010, pp. 169-172.

L. Cannari, M. Magnani and G. Pellegrini (2010b) Critica della ragione meridionale. II Sud e le politiche pubbliche (Laterza, Bari-Roma).

M. Carabba (2011) "Introduzione”, Rivista Giuridica del Mezzogiorno, XXV, 1-2/2011, pp. 713.

CNEL, Consulta per il Mezzogiorno (2010a) Programmazione 2007 - 2013 dei Fondi Europei e dei Fondi FAS: il punto di vista del partenariato socio-economico, Final Report, March 2010.

CNEL, Consulta per il Mezzogiorno (2010b) Indagine diretta presso le organizzazioni regionali del partenariato socio-economico sulla programmazione dei fondi strutturali e delle risorse FAS per il 2007-13, Annex to CNEL 2010, March 2010. 
Dipartimento per lo Sviluppo e la Coesione Economica (2010) Rapporto Annuale 2009 sugli Interventi nelle Aree Sottoutilizzate.

M. Draghi (2009) Intervento di apertura del Governatore della Banca d'Italia Mario Draghi al Seminario 'Il Mezzogiorno e la politica economica dell'Italia', Rome, 26 November 2009.

European Commission, Economic and Financial Affairs Directorate General (2010) European Economic Forecast - Spring 2010. European Economy 2/ 2010 (provisional version).

L. Franchetti (1911) "Mezzo secolo di unità nell'Italia meridionale", Rivista Giuridica del Mezzogiorno, XXV, 1-2/2011, pp. 17-36, reprint from "Nuova Antologia", tipografia della Camera dei Deputati, 1 May 1911.

D. Franco (2010) "L'economia del Mezzogiorno", in L. Cannari e D. Franco (eds.) II Mezzogiorno e la politica economica dell'Italia, Banca d'Italia, Seminari e convegni, no. 4, giugno 2010, 1-13.

R. Giordano, P. Tommasino and M. Casiraghi (2009) "Le determinanti dell'efficienza del settore pubblico: il ruolo della cultura e delle istituzioni", in L. Cannari (ed.) (2009) Mezzogiorno e politiche regionali. Banca d'Italia, Seminari e Convegni, 2, November 2009, pp. 253-275.

E. Gualini (2004) Multi-level Governance and Institutional Change. The Europeanization of Regional Policy in Italy, Ashgate.

A. Iona, L. Leonida and G. Sobbrio "Industrialization, convergence and governance", in A. Mammone and G. A. Veltri (2010) Italy Today. The Sick man of Europe, Routledge, pp. 201212.

A. Lepore (2011) “La valutazione dell'operato della Cassa per il Mezzogiorno e il suo ruolo strategico per lo sviluppo del Paese", Rivista Giuridica del Mezzogiorno, XXV, 1-2/ 2011, pp. 281-317.

I. Maes (2008) "The Spread of Keynesian Economics: A Comparison of the Belgian and Italian Experiences (1945-1970)", J ournal of the History of Economic Thought, 30, 4, pp. 491-509.

R. Michie (2011) "Programmes under Continued Pressure: Review of Programme Implementation Winter 2010 - Spring 2011", IQ-Net Review Paper, 28, 1.

Ministero per gli Affari Regionali? (unattributed) (2010) Piano Nazionale per il Sud. Le priorità per la stratrgia di ripresa sviluppo del Mezzogiorno,

Ministero dell'Economia e delle Finanze (2011) Documento di Economia e Finanza 2011. Sezione II: Analisi delle tendenze della Finanza Pubblica, Presentato dal Presidente del Consiglio dei Ministri Silvio Berlusconi e dal Ministro dell'Economia e delle Finanze Giulio Tremonti, deliberato dal Consiglio dei Ministri il 13 aprile 2011.

Ministero dell'Economia e delle finanze (2002) Documento di programmazione economicofinanziaria per gli anni 2003-2006 presentato dal presidente del Consiglio dei Ministri Silvio Berlusconi e dal Ministro dell'Economia e delle Finanze Giulio Tremonti, Deliberato dal Consiglio dei Ministri il 5 luglio 2002.

Ministero dell'Economia e delle finanze (2001) Documento di programmazione economicofinanziaria 2002-2006 (approvato dal Consiglio dei Ministri del 16 luglio 2001).

Ministero dello Sviluppo Economico (2009) Dipartimento per lo Sviluppo e la Coesione Economica, Rapporto Strategico Nazionale 2009, December 2009.

Ministero dello Sviluppo Economico, Dipartimento per le Politiche di Sviluppo e Coesione (2007) Quadro Strategico Nazionale per la Politica Regionale di Sviluppo 2007-2013, June 2007.

Ministero del Tesoro, Bilancio e Programmazione Economica (1998) Cento Idee per lo Sviluppo. Schede di Programma 2000-2006, December 1998.

N. Novacco (2010) SVIMEZ hearing in the framework of the parliamentary inquiry on the effectiveness of the expenditure and the policies for the support of underutilised areas, Rome 3 February 2010, V Commission, Budget, Treasury and Programming, p. 5 (Relazione 
del dott. Nino Novacco, Presidente della 'Associazione per lo sviluppo dell'industria nel Mezzogiorno', Audizione della SVIMEZ nell'ambito della 'Indagine conoscitiva sull'efficacia della spesa e delle politiche di sostegno alle aree sottoutilizzate')

R. Padovani (2011) Relazione al seminario promosso dalla SVIMEZ nell'ambito de "Le Giornate dell'Economia del Mezzogiorno", Palermo, 5 November 2010, in Quaderno SVIMEZ no. 28, May 2011.

L. Polverari and R. Vitale (2010) "Riflessioni sulla riforma della politica di coesione per il periodo 2014-2020: stato del dibattito e prospettive per I'Italia", Rivista Giuridica del Mezzogiorno, 4/ 2010, 1211-1252.

A. Rainoldi (2010 “Dal 1989 al 2009. Vent'anni di intervento del "Fondo europeo di sviluppo regionale" nel Mezzogiorno d'Italia: scelte allocative, utilizzo delle risorse e ruolo del fattore-tempo", Rivista Giuridica del Mezzogiorno, 1/2010, pp. 7-42.

P. Saraceno (1983) “Trent'anni di intervento straordinario (1951-1980), Studi Svimez, 36, 34, pp. 65-105.

G. Servidio and S. Prezioso (2011) “Industria meridionale e politica industriale dall'Unità d'Italia ad oggi", in Nord e Sud a 150 anni dall'Unità d'Italia, Sessioni di studio, Sessione II, I mutamenti della struttura economica: i settori e i mercati, Camera dei Deputati, Rome, 30 May 2011.

SVIMEZ (2011) Nord e Sud: insieme nella crisi, divergenti nella ripresa. Anticipazioni sui principali andamenti economici dal Rapporto SVIMEZ 2011 sull'economia del Mezzogiorno, Press Conference 29 J uly 2011, Rome.

SVIMEZ (2009) Rapporto SVIMEZ 2009 sull'economia del Mezzogiorno: Introduzione e sintesi, SVIMEZ, Roma.

R. Sykes (1998) "Italian public policy and the Southern Question: Policy disaster or political disaster?", in P. Gray and P.'t Hart (eds.) Public Policy Disasters in Western Europe (Routledge, London, 1998, pp. 81-98).

C. Trigilia (2010) “Il Piano per il Sud nasce zoppo. Dubbi sull'impianto istituzionale e sulle risorse finanziarie", II Sole 24 Ore, 27 November 2010).

Viesti, G. (2009) Mezzogiorno a tradimento. II Nord, il Sud e la politica che non c'è (Laterza, Bari).

Vision \& Value and The London School of Economics (2003) Rapporto di Valutazione Intermedia, Servizio di valutazione indipendente intermedia del QCS Ob. 1 2000-2006, 30 December 2003. 